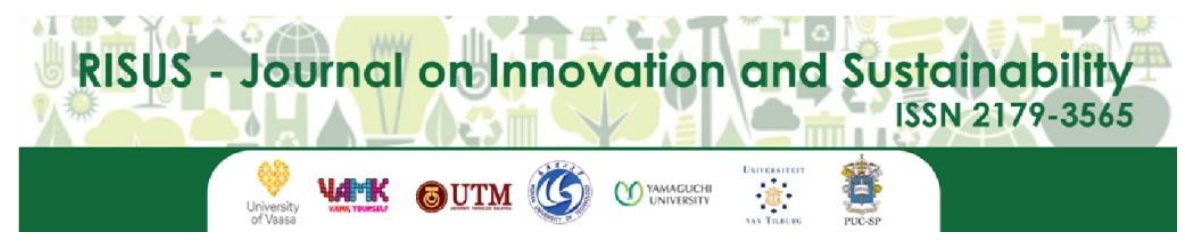

RISUS - Journal on Innovation and Sustainability volume 12, número $1-2021$

ISSN: $2179-3565$

Editor Científico: Arnoldo José de Hoyos Guevara Editor Assistente: Rosa Rizzi

Avaliação: Melhores práticas editoriais da ANPAD

\title{
SUSTAINABLE URBAN MOBILITY DIAGNOSIS: APPLICABILITY OF A COMPOSITE INDEX
}

Diagnóstico de mobilidade urbana sustentável: aplicação de um índice sintético

Renata Covisi Pereira, Bruna Angela Branchi, Denise Helena Lombardo Ferreira Pontifícia Universidade Católica de Campinas-PUC E-mail: renatacovisi@hotmail.com, bruna.branchi@puc-campinas.edu.br, lombardo@puc-campinas.edu.br

\begin{abstract}
Sustainable urban mobility adds a new dimension to the circulation of goods and people in the city: sustainability. The increasing number of individual motor vehicles is an accurate urban mobility diagnostic, by highlighting strengths and weaknesses, to guide public policies aimed at improving the quality of urban life. In this paper, the Sustainable Urban Mobility Index has been discussed and then applied to evaluate the sustainable urban mobility in Campinas (SP, Brazil). For the period 2010-2014, the index shows a persistent insufficiency in the sustainable urban mobility of this city, even if there was a slight improvement in the period. This is due to the environmental dimension, considering the increasing fuel consumption. It is therefore necessary to look for possible solutions involving primarily collective transportation and non-motorized one, especially for short distance.
\end{abstract}

Keywords: Urban mobility; Sustainable urban mobility index; Sustainability. 


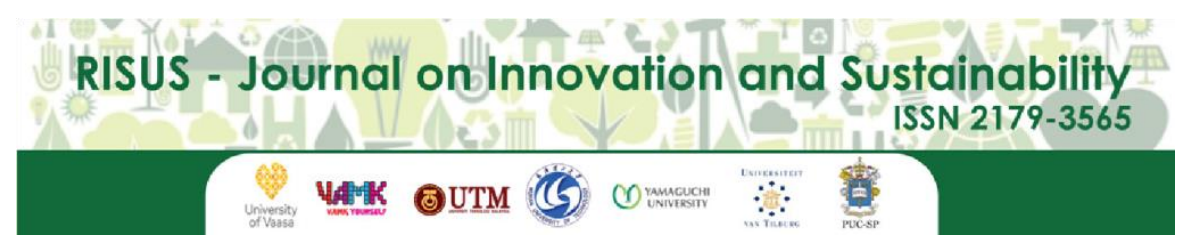

RISUS - Journal on Innovation and Sustainability volume 12, número $1-2021$ ISSN: 2179-3565

Editor Científico: Arnoldo José de Hoyos Guevara Editor Assistente: Rosa Rizzi Avaliação: Melhores práticas editoriais da ANPAD

\title{
DIAGNÓSTICO DE MOBILIDADE URBANA SUSTENTÁVEL: APLICAÇÃO DE UM ÍNDICE SINTÉTICO
}

Sustainable urban mobility diagnosis: applicability of a composite index

\author{
Renata Covisi Pereira, Bruna Angela Branchi, Denise Helena Lombardo Ferreira \\ Pontifícia Universidade Católica de Campinas-PUC \\ E-mail: renatacovisi@hotmail.com,bruna.branchi@puc-campinas.edu.br, \\ lombardo@puc-campinas.edu.br
}

\section{RESUMO}

O conceito de mobilidade urbana sustentável qualifica a circulação de mercadorias e pessoas pelo espaço das cidades adicionando o aspecto da sustentabilidade. O número crescente de veículos individuais motorizados impõe um caráter de urgência ao diagnóstico da mobilidade urbana, apontando limites e possibilidades, visando orientar as políticas públicas para melhorar a qualidade de vida urbana. O objetivo deste artigo é, portanto, avaliar a sustentabilidade da mobilidade urbana do município de Campinas/SP, por meio da construção e aplicação de Índice de Mobilidade Urbana Sustentável. Calculado para o período 2010-2014, o índice aponta para a insuficiência da mobilidade urbana sustentável, mesmo registrando uma leve melhora no período. A principal componente deste resultado é a dimensão ambiental, considerando o consumo crescente de combustíveis. É necessário, portanto, identificar possíveis soluções envolvendo prioritariamente os transportes públicos e modais não motorizados, particularmente de curta distância.

Palavras-chave: Mobilidade urbana; Índice de mobilidade urbana sustentável; Sustentabilidade. 


\section{INTRODUCTION}

Sustainable urban mobility can contribute to the well-being of the economy and society. The ways in which commuting occurs in the urban space should not harm human health and the environment, while fostering the access to the territory and to public services. It is essential to maintain economic sustainability from the costs and efficiency perspective by offering alternative transportation systems and taking care of the productive and regional dynamics. However, it is also necessary to limit waste, air, and noise pollution by using renewable resources, reducing non-renewables ones and land usage (OECD, 2000; Meira, 2013).

The social, environmental, and economic dimensions of sustainable urban mobility are intertwined. Mobility must be articulated in order to distribute benefits with social justice, with minimal environmental impacts and economic balance. For example, public transport strengthens social justice by promoting a more democratic access to the urban space. At the same time, the greater use of collective transportation can contribute to the reduction of individual motorized transportation, with environmental and health benefits by reducing pollution. Finally, the reduced number of motor vehicles on the streets has a positive economic impact, decreasing the time spent on the commute, as well as increasing productivity (Freitas et al., 2015).

Carvalho (2016) identifies a list of items that allows to qualify transportation systems as sustainable. Regarding the environmental sustainability dimension, the author highlights: a) clean technologies (less air pollution and noise); b) the use of vehicles adapted to the space availability, historical patrimony, or environmental preservation areas. On the economic sustainability dimension, he suggests a) balance between supply and demand for transportation; b) cost coverage; c) investment in the maintenance and expansion of transport networks; d) appropriate and viable financing models and remuneration of concessionary companies. In the case of social sustainability, he recommends a) adjustment between tariff values and the users' income; b) meeting the demand especially from outskirt areas; c) universalization of accessibility.

Based on the sustainable urban mobility concept outlined above, the next steps would be analysing the actual mobility in cities, identifying its strengths and weaknesses, and suggesting public policies that can improve the urban life quality and protect the environment.

In this article the objective is to diagnose sustainable urban mobility in the city of Campinas, state of São Paulo, Brazil.

Campinas is classified by the Brazilian Institute of Geography and Statistics (IBGE) as a "regional capital", that is, a city with a management capacity at the level immediately below that of a metropolis, which influence is limited to a regional area, being referred to as a destination, for a set of activities, by many municipalities (IBGE, 2007, p.11). Located less than $100 \mathrm{~km}$ from the capital of the State of São Paulo, it occupies a large area of 796.4 $\mathrm{km}^{2}$ (Prefeitura Municipal de Campinas, 2018). Campinas has an estimated population of over 1.15 million people in 2017, with a 98.3 percent of urbanization rate, and a Gross Domestic Product (GDP) of R 58.5 billion in 2016. It is an industrial and technological centre, home to many companies, universities, and research centres. The city fleet was composed by, in 2016, approximately 589 thousand cars and 5,400 buses (SEADE, 2018). The private owned share of this fleet grew at a faster rate than the urban collective transportation. While private cars and bus fleet grew by 18.7 percent and 25.2 percent respectively, public collective transportation increased by 5.7 percent. A clear result that transportation policies prioritize individual over collective options (SEADE, 2018).

Due to its size and economic relevance, Campinas can be considered as an appropriate place for the application of an indicator of sustainable urban mobility.

Therefore, to evaluate the quality of urban mobility in this city, a Sustainable Urban Mobility Index (IMUS) was developed and applied. The results are discussed in this article which, in addition to this introduction, is organized into three sections. The first section is devoted to outlining sustainable urban mobility according to the three dimensions cited. After that, a brief review of indicators and indexes of sustainable mobility is performed. In the next section the results of IMUS are calculated for Campinas (SP, Brazil) are presented to identify which aspects of sustainability are problematic for mobility in the city and which can be improved to achieve sustainable mobility. At last, the final considerations are presented. 


\section{THEORETICAL REFERENCE}

In this section, sustainable urban mobility will be addressed by synthesizing the three dimensions of sustainability: economic, social, and environmental. In addition, a brief review of the types of sustainable urban mobility measures is presented.

\section{Economic Dimension}

Urban infrastructure and the economic scenario, especially when dealing with the amount of available resources, affect the quantity and quality of public services, such as those related to mobility (Gomide, 2003). In contrast, mobility also affects the economic development of urban centres, by strengthening or weakening the local economy, according to the easiness and the accessibility of people to local markets (Meira, 2013).

The Brazilian choice to encourage road transportation came along with an additional stimulus of individual transportation. The ownership of a car is not only a status symbol, but it was also sustained by the reduction of the relative price of automobiles when compared to collective transportation (Vasconcellos; Mendonça, 2010). For example, between 1991 and 1996, bus fares grew more than inflation. At the same time, vehicle prices decreased because of a car tax reduction policy (Santos, 2009; Carvalho, 2016). The real price of cars suffered little variation, decreasing since 2007, meanwhile bus and subway fares, in real terms, continued to grow, accumulating a 200 percent increase between 1989 and 2013. This ascending trend lasted until 2013 when, by popular pressure, the tariffs were frozen which lead to a real reduction in the bus ticket (Carvalho, 2016). Therefore, increasing passengers' fares, along with the deterioration of the public transport service, is an incentive to diminish the collective means of transportation and to promote the ownership of private vehicles. The migration of passengers from public to individual modal is therefore rationally justified.

Basically, two factors could be held responsible for the rise in bus fares: a) increase in the cost of bus production, its operational consumables, such as diesel, tires, and maintenance parts; b) reduction of the number of paying passengers (Augustin, 2016). In the case of Campinas, Figure 1 allows to compare the evolution of the main items of urban collective transportation costs and the bus price stands out as the predominant cost component.

Figure 1: Bus fare and main components of the collective transportation costs (real annual variation), Campinas, 2010-2014.

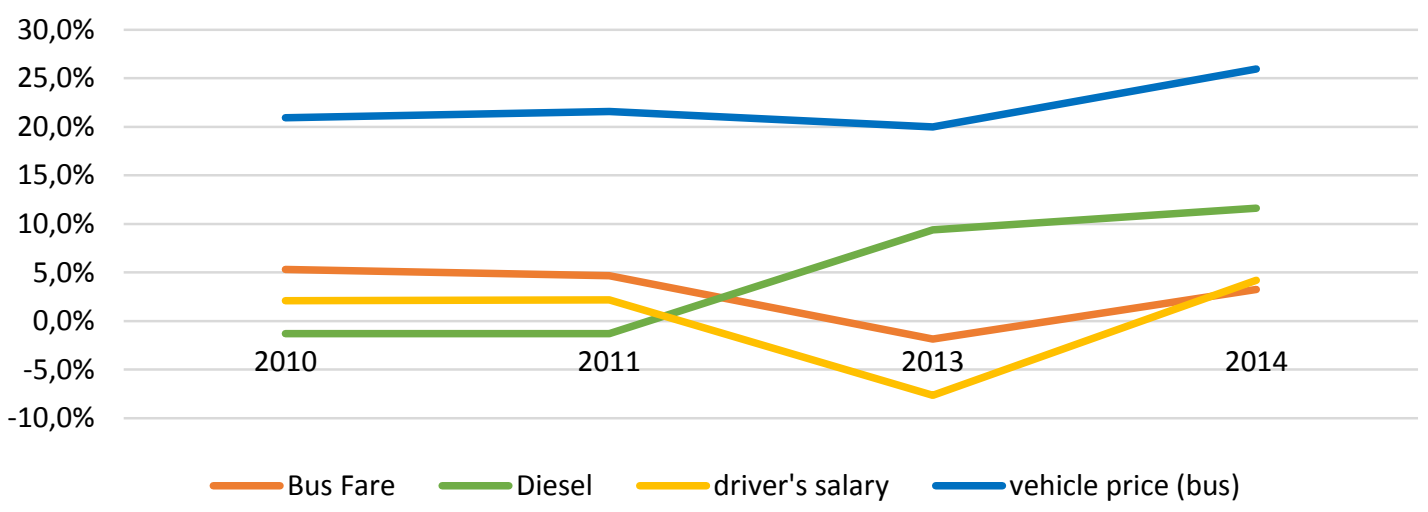

Note: Deflated by the Broad National Consumer Price Index (IPCA). Source: Elaborated by the authors with data from EMDEC (2010, 2011, 2013, 2014).

Starting from the increase in bus fares, the demand for public urban transportation is expected to fall. This provokes an additional ticket rise needed to counterbalance the revenue loss caused by the reduced number of passengers, thus starting a vicious cycle (Augustin, 2016). According to Figure 1, in Campinas the real tariff felt in 2013, echoing the popular pressure, but rapidly recovered one year later.

An additional third factor can help understanding the rising fare of public urban transportation in Brazil: reduced fares for students, the elderly, disabled, etc. According to the financing model used in Brazil, these 
benefits are taken into consideration when defining tariffs, burdening regular passengers, when paying the full tariff, with this additional cost. That is, since the captive users of collective transportation are mainly those with lower income, they are, directly or indirectly, supporting those in a more comfortable economic condition. Directly when bus fares reflect the cost of free passes for students or seniors with higher income. Indirectly when tax revenues are used for road improvements that mainly benefits private and individual transportation (Freitas et al., 2015).

The public manager who oversees the offering of this service, usually from the municipal level in Brazil, is subject to the financing, remuneration and pricing models defined by the National Urban Mobility Policy and to additional laws (Brasil, 2012). Most cities periodically review the tariffs based on the estimated total cost per route-kilometer. This estimate includes all fixed and operating costs as well as profit of the concessionaire company. It also includes gratuities, discounts and sometimes also subsidies. Therefore, the concessionary company has little incentive to reduce costs or optimize productivity (Augustin, 2016).

This financing model can make investments unfeasible. It is hard to maintain an economically viable collective transportation system where a continuous reduction in the number of passengers for whom high fares and poor quality of the service is making private transportation increasingly appealing. In addition, the lack of investment undermines expansion and improvement plans.

\section{Social Dimension}

Social justice is based on two precepts: merit and necessity. More than suppressing social inequalities or avoiding individuals to be excluded from society, social justice claims that everyone has equal rights, but also that individual human needs must be considered (Barzotto, 2003).

Starting from the use and occupation of urban land, in a disordered and unplanned way, spatial segregation occurs, which represents the distancing of people from the collective spaces of cities, manifesting itself with the creation of urban peripheries. Segregation rises the need for a necessary expansion of transportation services, since the spreading out of cities locates people to places far from urban centers and public services, limiting mobility (Gomide, 2003). The number and frequency of these connecting lines usually are not enough to meet the commuters demand, especially because urban suburbs are high-density areas, home of captive users of public transport (Freitas et al., 2015).

Furthermore, urban collective transport has the potential to promote social inclusion directly by offering a basic service that affect those who depend on urban collective transportation to access public facilities and social services and job opportunities (Gomide, 2003). The percentage of the family budget spent on transportation is significant, especially for low-income families, which means that investments in better urban collective transportation system can have a progressive effect on income distribution (Gomide, 2003).

Indirectly by facilitating economies of scale and scope of business located in urban areas, with positive consequences on productivity, employment, and income. Entrepreneurs, for example, could be encouraged to create or expand production units where the labour cost is lower. Cities with efficient urban collective transportation system have a potential to attract business by lowering one important labour cost component, that related to workers' commuting.

In addition to this, with an efficient transportation system, workers can benefit from an increase in their spare time which they can freely spent in other income generation activities or leisure.

\section{Environmental Dimension}

The environmental dimension is undoubtedly affected by urban mobility in many forms. By using vehicles, several impacts can occur, among them the depletion of natural resources, such as oil; climate change with the emission of global pollutants and changes in microclimates by local pollutants; generation of waste from discarded vehicles and depreciated buses; loss of public spaces and green areas to provide transport infrastructures; and noise emission (Campos, 2006). 
Negative environmental impacts of urban mobility can be classified as negative externalities because they are not accounted for as cost by fuel and car industry or by transport operators. ${ }^{1}$

The most visible environmental impact felt by the population is air pollution. Fossil fuels are largely used to move buses and cars in Brazil. The burning of fossil fuels increases greenhouse gases enabling the development of respiratory, cardiovascular and cancer diseases. Air pollution has also economic consequences since undermining human health has negative impacts on workers' productivity (Antenor et al., 2010).

There is a wide variety of pollutants released by vehicles, such as: a) volatile organic compounds, which combine and form ozone near the ground, which can cause lung diseases; b) greenhouse gases: methane $\left(\mathrm{CH}_{4}\right)$, nitrous oxide $\left(\mathrm{N}_{2} \mathrm{O}\right)$ and above all carbon dioxide $\left(\mathrm{CO}_{2}\right)$. Environmentally, the emission of pollutants also causes acid rain that damages vegetation, buildings, river water, etc. (Motta et al., 2007).

Sound pollution is another consequence of transport. Vehicle traffic is the biggest cause of noise in big cities. Depending on the individual exposure time and levels, irreversible hearing loss may occur, as well as the reduction of temporary hearing capacity in short-term exposures (Giuliani, 2011).

In addition to the atmospheric and noise pollution, there is also the visual one related to the number of vehicles moving around the city. More, the city infrastructure must follow the vehicles growth, modifying the use and occupation of urban space, and consequently its value. Solid waste and effluent must also be considered, since, if not properly treated, they can harm health and the environment (Motta et al., 2007).

Looking at the environmental side, especially due to the expected increase-in urban population, it is necessary to discuss ways of investing in public urban transportation, both to improve mobility quality and to use clean and renewable energy (Campos, 2006). It is worth remembering that, ceteris paribus, collective transport emits three times less pollutants per passenger than the individual transport (Motta et al., 2007).

\section{Measures of Sustainable Urban Mobility: a Synthesis}

The use of indicators for sustainability assessment began at the Rio 92 Conference, where, in its final document Agenda 21, it can be found a critique to the use of GDP and other common environmental indicators to monitor the sustainable development. The document stressed the need for developing indicators of sustainable development considering environmental, economic, and social factors as well as improving data collection and method of data analysis (UN, 1992).

Since then, the use of sustainability indicators and indexes has become more common in academic and business discussions. They are seen as important elements for building scenarios, formulating diagnoses, and suggesting solutions to various problems. Given that "... an index is the final aggregate value of an entire calculation procedure where indicators are basic elements that compose it" (Siche et al., 2007, p.139), sustainability indexes represent useful and efficient tools for monitoring sustainability. For this reason, this research focuses on a composite index to assess sustainable urban mobility.

More, for an index to be used effectively, it must be relevant, precise, simple, and easy to understand (Joumard; Gudmundsson, 2010). In addition to the relevance, one of the criteria for selecting an index should also be the analytical correction (OECD, 1993).

According to Guimarães e Feichas (2000, p. 309) "a notion of economic value that encompasses environmental goods and services, however arbitrary it may be, is more effective than the inexistence of any parameters". On the other side, given the high complexity of ecosystems and society, indicators and indexes of any kind are always limited representation of the reality (Guimarães and Feichas, 2009).

Notwithstanding a wide variety of indexes and indicators has been used, at national, local, or sectoral level. One of the first example was carried out by the World Bank, together with the International Institute for Sustainable Development and other organizations. They published a study of indicators used worldwide for environmental and sustainability analysis up to 1999 (Machado, 2010).

For urban areas, the Habitat Urban Indicators Program was the first initiative to systematize environmental data related to urban life. It was followed by other actions, such as those of the Economic Commission for Latin

\footnotetext{
${ }^{1}$ The externalities are actions from producers or consumers that impact other economic agents and are not valued (Pindyck; Rubinfeld, 2006).
} 
America and the Caribbean and the World Bank, in an international context, and that of IBGE and the Ministry of Cities, for the Brazilian experience (Machado et al., 2012).

Following this trend, more initiatives have emerged to systematize mobility indicators at the international level, among which: Sustainable Mobility, Policy Measures and Assessment, which reviewed and classified indicators of various organizations; Mobility 2030, which brought together 12 proposed indicators to measure sustainable mobility; Leeds Transport Studies Institute, with the evaluation of 17 indicators related to transport; Victoria Transport Policy Institute, that carried out the research and classification of indicators according to criteria of potential application or relevance, considering the environmental, economic and social dimensions; Scientific Forum on Transport Forecast, that studied European projects, indicators and scenarios for transportation, in order to reach consensus on methodology, measurement and forecast; Set of Spanish Indicators, which focused too on the systematization of indicators (Machado, 2010).

In Brazil, such interest became more evident since the 2000s, with the IQVU-BR System; the Sustainable Urban Mobility Index (IMUS); Sustainable Mobility Indicators relating the land use and occupation to transporting; the Urban Mobility Information System of the National Association of Public Transport; the Collective transportation Adequacy Index and the Urban Planning and Integrated Sustainable Transport (Machado, 2010).

The IQVU-BR system, proposed by Nahas (2002), has been used to guide the Belo Horizonte municipal management when allocating its budget, giving voice to the population demand for services and urban infrastructure.

Campos and Ramos (2005) proposed a set of sustainable mobility indicators that relates land use and occupation to transportation, aiming at evaluating and promoting sustainability in cities. They used characteristics of the urban structure that encourage the use of bicycle and walking.

ANTP's Urban Mobility Information System collects data related to collective transportation and traffic in Brazilian cities with more than 60 thousand inhabitants. It includes information on the socioeconomic situation of municipalities, data related to the distance and time spent on commuting via different transportation modes in the municipal and metropolitan areas, the energy used, the environmental and social expenses and the emissions of pollutants (ANTP, 2015).

The system of PLANning Urban Transportation integrated and Sustainable systems (PLANUTS), proposed by Magagnin (2008), aimed to become a computational tool. At the same time, it can be used to support the decisions taken in the field of urban mobility in master plans of small and medium-sized cities, as well as the definition of a set of indicators for the evaluation of urban mobility.

The IMUS, with a methodology close to the one used in this research, was proposed by Costa (2008) as a tool for controlling and managing mobility in medium-sized cities. The author built a hierarchy of criteria that aggregates nine areas, thirty-seven themes and eighty-seven indicators. Its weight choice allows identifying the relative importance of each dimension of sustainability (social, economic, and environmental). Finally, by aggregating the partial indices, one for each dimension studied, a global index of sustainable mobility is calculated (Costa, 2008, p. ix).

Ribeiro (2017) applied the methodology proposed by Costa (2008) to the municipality of Campinas. As a result, from a dataset of 76 indicators collected, 15 indicators were identified as critical for city mobility. These indicators are mainly related to the option chosen by the municipal management to privilege individual vehicles to the detriment of urban collective transportation. Limited and onerous data and the lack of transparency corroborates with the short-term view of the public administration according to Ribeiro (2017).

\section{RESEARCH METHOD}

Machado et al. (2012) developed a mobility index for Metropolitan Area of Porto Alegre, based on the three dimensions of sustainable development, to evaluate how transport and mobility affect each one of them. Their methodology inspired the IMUS proposed in this paper for the city of Campinas.

The variables used for each one of the three dimensions are detailed in Table 1. 
Table 1: Definitions of the Variables of the Campinas Urban Sustainable Mobility Index.

\begin{tabular}{|c|c|c|c|}
\hline Dimension & Variable & $\begin{array}{c}\text { Definition } \\
\end{array}$ & Source \\
\hline \multirow[b]{2}{*}{ Social } & $\begin{array}{l}\text { SOC1: Accidents } \\
\text { with Deaths }\end{array}$ & $\begin{array}{l}\text { Deaths in traffic accidents as a } \\
\text { proportion of the number of licensed } \\
\text { vehicles. } \\
\text { Number of trips per capita, (tariff } \\
\text { revenue }^{1} \text { divided by the value of the } \\
\text { ticket annually, without excluding } \\
\text { the gratuities and discounts, divided } \\
\text { by the city habitants). }\end{array}$ & $\begin{array}{l}\text { SEADE (2018); Cidades } \\
\text { Sustentáveis (2018a). }\end{array}$ \\
\hline & $\begin{array}{l}\text { SOC2: } \\
\text { Collective } \\
\text { Transportation } \\
\text { supply } \\
\text { SOC3: Accessibility }\end{array}$ & $\begin{array}{l}\text { Rate of expenses with adapted lifts, } \\
\text { both for general buses and for those } \\
\text { related to the Inclusive Accessibility } \\
\text { Program (PAI) (per capita). }\end{array}$ & $\begin{array}{l}\text { EMDEC (2010); EMDEC } \\
\text { (2011); EMDEC (2013); } \\
\text { EMDEC (2014); SEADE } \\
\text { (2018); TRANSURC } \\
\text { (2018). } \\
\text { EMDEC (2010); EMDEC } \\
\text { (2011); EMDEC (2013); } \\
\text { EMDEC (2014); SEADE } \\
\text { (2018). }\end{array}$ \\
\hline \multirow{3}{*}{ Economic } & $\begin{array}{l}\text { ECO1: } \\
\text { Family } \\
\text { Transportation } \\
\text { Budget }\end{array}$ & $\begin{array}{l}\text { Workers' monthly expenditure with } \\
\text { bus tickets as a proportion of the } \\
\text { minimum wage (considering twenty } \\
\text { working days and round trip). }\end{array}$ & $\begin{array}{l}\text { EMDEC (2010); EMDEC } \\
\text { (2011); EMDEC (2013); } \\
\text { EMDEC (2014); DIEESE } \\
\text { (2018); TRANSURC } \\
\text { (2018). }\end{array}$ \\
\hline & $\begin{array}{l}\text { ECO2: Collective } \\
\text { Transportation } \\
\text { Efficiency }\end{array}$ & $\begin{array}{l}\text { Index of passengers per kilometer, } \\
\text { calculated through the average } \\
\text { annual route divided by the number } \\
\text { of annual trips. }\end{array}$ & $\begin{array}{l}\text { EMDEC (2010); EMDEC } \\
\text { (2011); EMDEC (2013); } \\
\text { EMDEC (2014). }\end{array}$ \\
\hline & $\begin{array}{l}\text { ECO3: Public } \\
\text { Investment }\end{array}$ & $\begin{array}{l}\text { Ratio between the transport sector } \\
\text { expenditures and municipal GDP. }\end{array}$ & $\begin{array}{l}\text { SEADE (2018); Cidades } \\
\text { Sustentáveis (2018b). }\end{array}$ \\
\hline \multirow{3}{*}{ Environmental } & $\begin{array}{l}\text { AMB1: } \\
\text { Motorization Rate }\end{array}$ & $\begin{array}{l}\text { Number of vehicles in circulation } \\
\text { (per capita). }\end{array}$ & SEADE (2018). \\
\hline & $\begin{array}{l}\text { AMB2: Fossil Fuel } \\
\text { Consumption }\end{array}$ & $\begin{array}{l}\text { Gas and diesel per capita } \\
\text { expenditure (in Brazilian Real). }\end{array}$ & $\begin{array}{l}\text { ANP (2010); ANP } \\
\text { (2011); ANP (2012); } \\
\text { ANP (2013); ANP } \\
\text { (2014). }\end{array}$ \\
\hline & $\begin{array}{l}\text { AMB3: } \\
\text { Consumption of } \\
\text { Alternative Fuels }\end{array}$ & $\begin{array}{l}\text { Per capita expenditure in hydrated } \\
\text { alcohol (in Brazilian Real). }\end{array}$ & $\begin{array}{l}\text { ANP (2010); ANP } \\
\text { (2011); ANP (2012); } \\
\text { ANP (2013); ANP } \\
\text { (2014). }\end{array}$ \\
\hline
\end{tabular}

Notes:

1. For the year 2012 there was no data on the tariff revenue, therefore, interpolation was used to estimate the value in the series.

2. For the year 2012, missing data on adapted elevators expenses led to the use of interpolation to estimate the value in the series. Source: Own elaboration based on Machado et al. (2012).

The raw data collected for each variable indicated in Table 1 were standardized according to Equation 1.

$$
\mathrm{I}_{\mathrm{i}}=\frac{\text { variável (i) - mínimo (i) }}{\text { máximo (i)-mínimo (i) }}
$$

Where:

variable (i) is one of the nine chosen variables (for example Accidents with deaths); 
minimum (i) and maximum (i) are the minimum and maximum values recorded for the chosen variable, respectively;

$\mathrm{I}_{\mathrm{i}}=$ index number, which varies from 0 to 1 , associated to the chosen variable (for example SOC1 if the variable is Accidents with deaths).

Each variable is then evaluated based on its influence (positive or negative) on sustainable urban mobility. For example, the second social indicator, SOC2, refers to the collective transport supply in the municipality, which is positively correlated to urban mobility. Therefore, this indicator is included with a positive sign in the IMUS procedure. On the other side, the first social indicator, SOC1, which refers to fatal accidents, is negatively correlated to sustainable mobility. Consequently, it is included in the IMUS with a negative sign.

In the following step, partial indexes (social, economic, and environmental) are calculated as weighted average of all standardized variables, multiplied by the direction of the desired influence. Two different forms of obtaining these partial indexes were used. One of them inspired by the work of Machado et al. (2012), based on the expert opinions from the local municipalities of cities included in Metropolitan Region of Porto Alegre.

The first estimate (IMUS1) was elaborated by assigning equal weights to each one the three dimensions as well as to each variable in the partial indices. This estimate is a sort of benchmark used to perform a comparative analysis on the importance of weight assignment.

Equations 2, 3 and 4 represent algebraically the calculation of the partial indices of IMUS1:

$$
\begin{aligned}
& \mathrm{ISOC}=\frac{-\mathrm{SOC} 1+\mathrm{SOC} 2+\mathrm{SOC} 3}{3} \\
& \mathrm{IECO}=\frac{-\mathrm{ECO} 1+\mathrm{ECO} 2+\mathrm{ECO} 3}{3} \\
& \mathrm{IAMB}=\frac{-\mathrm{AMB} 1-\mathrm{AMB} 2-\mathrm{AMB} 3}{3}
\end{aligned}
$$

Therefore, the IMUS1 is obtained as the average of the three partial indices:

$$
\text { IMUS1 }=\frac{\mathrm{SOC}+\mathrm{ECO}+\mathrm{AMB}}{3}
$$

For the second estimate (IMUS2), different weights were used for each selected variable. The weights were the result of a research carried out, mainly, with agents professionally related to urban mobility in the city of Campinas. Invitations to participate in the survey were sent to the following departments:

- $\quad$ Executive Coordination of Support to Councils and Municipal Funds;

- $\quad$ Sectorial Coordination of Physical-Territorial Planning and Development;

- $\quad$ Department of Planning and Urban Development;

- Department of Green and Sustainable Development;

- $\quad$ EMDEC;

- $\quad$ Post-Graduation Program in Civil-Transport Engineering (Unicamp);

- $\quad$ Post-Graduation Program in Urban Infrastructure (PUC-Campinas);

- $\quad$ Secretary of Planning and Urban Development;

- $\quad$ Secretary of Green, Environment and Sustainable Development;

- $\quad$ Secretary of Municipal Urbanism.

The questionnaire elaborated and applied electronically obtained 10 answers.

The participants had to classify each set of variables (the same listed in Table 1) from 1 (least important) to 3 (most important). Their answers were transformed into arithmetic averages and standardized so that the sum of them were 1 .

The results, in Table 2, informs the weights used to calculate the IMUS2. 
Table 2: Weights for each IMUS2 components.

\begin{tabular}{cccc}
\hline Dimension & Weight & Indicator & Weight \\
\hline \multirow{3}{*}{ SOC } & 0,4333 & 2 & 0,333 \\
& & 1 & 0,283 \\
& & 3 & 0,383 \\
\hline \multirow{3}{*}{ ECO } & 0,2667 & 2 & 0,250 \\
& & 1 & 0,316 \\
\hline \multirow{2}{*}{ AMB } & 0,3000 & 2 & 0,333 \\
& & 1 & 0,300 \\
& & 3 & 0,366 \\
\hline
\end{tabular}

Source: Own elaboration.

Equations 6, 7 and 8 summarize the IMUS2 partial indices calculations, respectively.

$\mathrm{ISOC}=-\mathrm{SOC} 1 * 0,33+\mathrm{SOC} 2 * 0,28+\mathrm{SOC} 3 * 0,38$
$\mathrm{IECO}=-\mathrm{ECO} 1 * 0,43+\mathrm{ECO} 2 * 0,25+\mathrm{ECO} 3 * 0,31$
$\mathrm{IAMB}=-\mathrm{AMB} 1 * 0,30-\mathrm{AMB} 2 * 0,33-\mathrm{AMB} 3 * 0,36$

For IMUS2, Equation 9 represents its estimate:

IMUS2 $=\mathrm{SOC} * 0,43+\mathrm{ECO} * 0,26+\mathrm{AMB} * 0,3$

\section{RESULTS AND DISCUSSION}

In Table 3, the two sustainable mobility indexes for Campinas are presented, along with their components.

Table 1. Partial and total indices (IMUS1 and IMUS2), Campinas, 2010-2014.

\begin{tabular}{l|llll|llll}
\hline & \multicolumn{4}{|c|}{ Methodology 1 } & \multicolumn{4}{c}{ Methodology 2 } \\
\hline Year & ISOC & IECO & IAMB & IMUS1 & ISOC & IECO & IAMB & IMUS2 \\
\hline 2010 & 0,333 & $-0,279$ & $-0,333$ & $-0,093$ & 0,283 & $-0,362$ & $-0,366$ & $-0,213$ \\
2011 & 0,011 & $-0,097$ & $-0,449$ & $-0,179$ & 0,013 & $-0,243$ & $-0,445$ & $-0,264$ \\
2012 & 0,199 & 0,247 & $-0,556$ & $-0,037$ & 0,224 & 0,109 & $-0,533$ & $-0,099$ \\
2013 & 0,051 & 0,525 & $-0,693$ & $-0,039$ & 0,100 & 0,432 & $-0,670$ & $-0,500$ \\
2014 & $-0,115$ & 0,557 & $-0,718$ & $-0,092$ & $-0,086$ & 0,454 & $-0,696$ & $-0,094$ \\
\hline
\end{tabular}

Source: Own elaboration.

Both measures present the same trend, allowing to define a range of values to evaluate the sustainable urban mobility in Campinas. As it can be seen, the IMUS2 always identifies greater deficits in urban mobility in Campinas in this period. The different weights (Table 3) used in the IMUS2 reduce the economic influence and reinforce the importance of the social dimension, followed by the environmental one. The social component, over

the period, went from positive to negative in 2014, which means a fast deterioration in the social justice in the period. This negative evolution can be attributed to the increase in fatal accidents, to the decrease in the collective transportation offer and the city accessibility. As previously explained, bus fares suffered an increase which is relative stronger that the rise in car prices, which stimulates the acquisition of individual motor vehicles, reducing the demand for collective transportation. The following decreased revenues from collective transportation service lead to a reduction in the supply of collective transportation, in a vicious cycle. 
Opposite tendency characterized the partial economic index that recorded an improvement, reversing its signal in 2012. Possible explanations for this growth can be found in the reduction of household budget spent on transportation, and to the improvement in the efficiency of collective transportation as well as in the increase of public investment.

The environmental index, in turn, contributed negatively to the IMUS, since both the number of cars as well as the amount of fuel used have been constantly growing in the city.

Figure 2 summarizes these tendencies of the Sustainable Urban Mobility Index of Campinas city between the years 2010 and 2014. Graphically, both indexes capture the same negative trend for the sustainable mobility, with IMUS2 describing a worse picture than IMUS1.

Figure 2: Comparison of the results of IMUS1 and IMUS2, Campinas, 2010-2014.

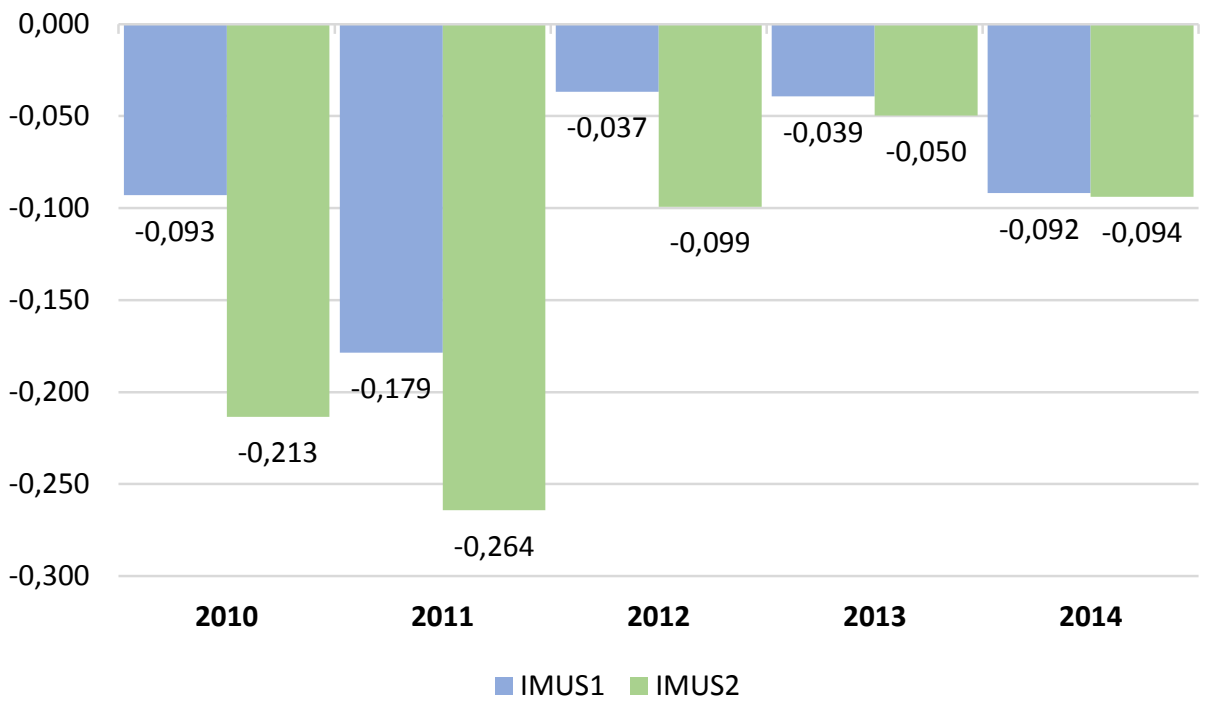

Source: Own elaboration.

If 2011 is the worst year, after improving in 2012 and 2013, the IMUS worsen again in 2014. Responsible for such changes is mainly the environmental component, followed by the social dimension. This is mainly due to the increase in the number of vehicles per capita in circulation in the city and the consequent increase in fuel consumption. Similarly, to the vicious cycle commented in the tariff case, a cycle can be identified when dealing with fatal mobility accidents. The increased number of cars in the city streets tends to rise the number of accidents. Consequently, public health costs increase, consuming the municipal budget that could contribute to improvements in collective transportation.

Urban collective transportation, if offered respecting the sustainability limits, that is being economically viable, contributing to social justice and reducing its environmental impacts, can be considered the common thread of sustainable mobility of cities, opening space for the population to be well served, reducing poverty, and promoting social inclusion in urban space (Gomide, 2003).

Thus, sustainable urban mobility policies should include urban collective transportation and consider it as a determinant of social inclusion for lower income classes, especially those excluded from the formal labour market. In this way, urban collective transport and non-motorized transport should be prioritized (Gomide, 2003).

\section{CONCLUSION}

The dynamics of cities have changed over the last few years, being influenced by new technologies, population, and vehicles growth. Sustainability is a concept that can contribute to improve the quality of life, especially in major urban centres. Studies discussing the available technological options, such as fossil fuels, biodiesel, electricity, and hydrogen, are needed to help finding the best solution when the goal is sustainable development. 
As pointed out in this paper, using the IMUS, the negative assessment of the sustainable mobility in Campinas is mainly due to the environmental dimension, because of the increasing number of vehicles circulating in the city.

The exponential increase in the number of individual motor vehicles extrapolates the municipal area of action, since public policies for supporting the automotive sector, a relevant sector for employment and income generation, are Federal Government policies.

However, the city administration must ensure that its collective transportation system and modal integration structure lead its citizens toward reducing the use of cars, as well as to foster the use of alternative fuels by increasing their use in public collective buses. Thus, reducing emissions of pollutants harmful to human health and the environment.

The need for assessing changes in the urban sustainable mobility is limited by the availability of data. This was evident in this research where data were incomplete and not rapidly updated for the city of Campinas, as well as geographical limited, given the impossibility of expanding the study to the Metropolitan Region of Campinas. This problem carries on consequences when dealing with the municipality supervision of concessionary companies, as well as the lack of transparency in internal processes to the municipal administration itself.

Despite of all restrictions, the IMUS here proposed can be part of the elaboration of a mobility monitoring plan for the city of Campinas, as well as, hopefully, for its Metropolitan Region.

\section{REFERENCES}

ANP - Agência Nacional do Petróleo, Gás Natural e Biocombustíveis. Dados estatísticos de vendas anuais de etanol hidratado e derivados de petróleo por município. Brasília: ANP, 2010 - 2014.

ANTENOR, S.; ANDRADE, R.; MACHADO-FILHO, M. F. Trânsito e aumento da frota de veículos tornam vulneráveis a saúde nas cidades. Ciência e Cultura, 62(4), 8-10, 2010.

ANTP - Associação Nacional do Transporte Público. Sistema de Informações da Mobilidade Urbana. Relatório Geral 2013, Brasília: ANTP, 2015.

AUGUSTIN, A. C. Evolução da tarifa de ônibus e do custo do transporte individual em Porto Alegre. Indicadores Econômicos FEE, 44(1), 107-120, 2016.

BARZOTTO, F. Justiça Social-Gênese, estrutura e aplicação de um conceito. Revista Jurídica da Presidência, 5 (48), 3-23, 2003.

BRASIL. Lei $\mathrm{n}^{\mathrm{o}}$ 12587, de 03 de janeiro de 2012. Institui as diretrizes da Política Nacional de Mobilidade Urbana; revoga dispositivos dos Decretos-Leis nos 3.326, de 3 de junho de 1941, e 5.405, de 13 de abril de 1943, da Consolidação das Leis do Trabalho (CLT), aprovada pelo Decreto-Lei no 5.452, de 1o de maio de 1943, e das Leis nos 5.917, de 10 de setembro de 1973, e 6.261, de 14 de novembro de 1975; e dá outras providências. Diário Oficial da União. Brasília, DF, 04 jan. 2012.

CAMPOS, V. B. G.; RAMOS, R. A. R. Proposta de indicadores de mobilidade urbana sustentável relacionando transporte e uso do solo. Paper presented at Congresso Luso Brasileiro para o Planejamento, Urbano, Regional,

Integrado, Sustentável-PLURIS. Anais. São Carlos: Escola de Engenharia de São Carlos, Universidade de São Paulo, 2005.

CAMPOS, V. B. G. Uma visão da mobilidade urbana sustentável. Revista dos Transportes Públicos 2, 99-106, 2006. 
CARVALHO, C. H. R. Desafios da mobilidade urbana no Brasil. Texto para Discussão n. 2198, Brasília: IPEA, 2016.

CIDADES SUSTENTÁVEIS. Acidentes de Trânsito. São Paulo: Cidades Sustentáveis, 2018a.

CIDADES SUSTENTÁVEIS. Orçamento de Transporte Destinado a transporte público São Paulo: Cidades Sustentáveis, 2018 b.

COSTA, M. S. Um índice de mobilidade urbana sustentável. Tese (Doutorado). Programa de Pós-Graduação em Engenharia Civil: Transportes. Universidade de São Paulo,

São Carlos, 2008

DIEESE - Departamento Intersindical de Estatística e Estudos Socioeconômicos. Pesquisa nacional da Cesta Básica de Alimentos. Salário-mínimo nominal e necessário. São Paulo: DIEESE, 2018.

EMDEC - Empresa Municipal de Desenvolvimento de Campinas. Estudo Tarifário 2010. Campinas: EMDEC, $2011-2105$.

FREITAS, P.; SILVEIRA, J.; SILVA, G.; SILVA, C. Mobilidade Urbana Sustentável: Problemas e Soluções. Revista Científica ANAP, 8(12), 01-17, 2015.

GIULIANI, A. O nível de ruído próximo aos motoristas de ônibus urbano na cidade de Porto Alegre, RS. Revista Liberato, 12(17), 97-103, 2011.

GOMIDE, A. A. Transporte urbano e inclusão social: elementos para políticas públicas. Texto para Discussão $\mathrm{n}$. 0960, Brasília: IPEA, 2003.

GUIMARÃES, R.; FEICHAS, S. Desafios na construção de indicadores de sustentabilidade. Ambiente \& Sociedade [online], 12, 307-323, 2009.

IBGE - Instituto Brasileiro de Geografia e Estatística. Região de Influência das Cidades 2007. Brasília: IBGE, 2007.

IBGE - Instituto Brasileiro de Geografia e Estatística. Produto Interno Bruto dos Municípios. Brasília: IBGE, 2018.

JOUMARD, R.; GUDMUNDSSON, H. Indicators of environmental sustainability in transport: An Interdisciplinary Approach to Methods. Recherches, Les collections de l'INRETS, May 2010.

MACHADO, L. Índice de Mobilidade Sustentável para Avaliar a Qualidade de Vida Urbana: estudo de caso Região Metropolitana de Porto Alegre - RMPA. Dissertação (Mestrado). Programa de Pós-Graduação em Planejamento Urbano e Regional, Faculdade de Arquitetura, Universidade Federal do Rio Grande do Sul, Porto Alegre, 2010.

MACHADO, L.; DOMINGUEZ, E.; MIKUSOVA, M. Proposta de índice de mobilidade sustentável: metodologia e aplicabilidade. Cadernos Metrópole 14(28), 529-552, 2012.

MAGAGNIN, R. C. Um sistema de suporte à decisão na internet para o planejamento da mobilidade urbana. Tese (Doutorado). Programa de Pós-Graduação em Engenharia Civil: Transportes. Universidade de São Paulo, São Carlos, 2008. 
MEIRA, L. H. Políticas Públicas de Mobilidade Sustentável no Brasil: Barreiras e Desafios. Tese (Doutorado). Programa de Pós-graduação de Engenharia Civil, Centro de Tecnologia e Geociências, Universidade Federal de Pernambuco, Recife, 2013.

MOTTA, R. A.; RIBEIRO, S. K.; PORTUGAL, L. S. Análise crítica de corredores de ônibus sob o ponto de vista ambiental. Revista dos Transportes Públicos da Associação Nacional dos Transportes Públicos-ANTP, 30, 45-54, 2007.

NAHAS, M. I. T. Bases teóricas, metodologia de elaboração e aplicabilidade de indicadores intra-urbanos na gestão municipal da qualidade de vida urbana em grandes cidades: o caso de Belo Horizonte. Tese (Doutorado). Programa de Pós-graduação em Ecologia e Recursos Naturais, Centro de Ciências Biológica e da Saúde, Universidade Federal de São Carlos, 2002.

OECD - Organization for Economic Co-operation and Development. OECD core set of indicators for environmental performance reviews. Environment Monographs, 83,1993.

PINDYCK, R. S.; RUBINFELD, D. L. Microeconomia. São Paulo: Pearson Prentice Hall, 2006.

PREFEITURA MUNICIPAL DE CAMPINAS. Dados Geográficos do Município. Campinas, Prefeitura Municipal de Campinas, 2018.

RIBEIRO, F. H. S. Expansão Urbana e Mobilidade: Planejando Cidades Multimodais Dissertação (Mestrado). Programa de Pós-Graduação em Sistemas de Infraestrutura Urbana, Pontifícia Universidade Católica de Campinas, 2017

SANTOS, A. T. Abertura comercial na década de 1990 e os impactos na indústria automobilística. Fronteira: revista de iniciação científica em Relações Internacionais, 8(16), 107-129, 2009.

SEADE - Fundação Sistema Estadual de Análise de Dados. Informações dos Municípios Paulistas. São Paulo: SEADE, 2018.

SICHE, R.; AGOSTINHO, F.; ORTEGA, E.; ROMEIRO, A. Índices versus indicadores: precisões conceituais na discussão da sustentabilidade de países. Ambiente \& Sociedade, 10, 137-148, 2007.

TRANSURC - Associação das Empresas de Transporte Coletivo Urbano de Campinas. Histórico da Tarifa. Campinas: TRANSURC, 2018.

VASCONCELLOS, E. A.; MENDONÇA, A. Política Nacional de Transporte Público no Brasil: organização e implantação de corredores de ônibus. Revista dos Transportes Públicos da Associação Nacional dos Transportes Públicos - ANTP, 33, 73-95, 2010.

UN - United Nations. Agenda 21. Rio de Janeiro: UN, 1992. 